\title{
Pengaruh Kualitas Fasilitas Wisata Terhadap Kepuasan Pengunjung Pemandian Air Panas “Aek Milas Siabu” Kabupaten Mandailing Natal
}

\section{Muhammad Isa}

Institut Agama Islam Negeri Padangsidimpuan

misastmm@gmail.com

\begin{abstract}
Abstrak Penelitian ini bertujuan untuk mengetahui pengaruh variabel kualitas fasilitas wisata terhadap kepuasan pengunjung pemandian air panas Aek Milas Siabu. Penelitian ini dilatarbelakangi oleh adanya keluhan pengunjung tentang kualitas fasilitas wisata yang ada di lokasi pemandian air panas Aek Milas Siabu yang buruk dan belum memuaskan mereka. Penelitian ini adalah penelitian kuantitatif dengan teknik regresi linear sederhana. Pengumpulan data menggunakan angket yang disebar kepada 69 orang responden. Pengolahan data dilakukan dengan bantuan software SPSS. Dari penelitian yang dilakukan ditemukan bahwa variabel kualitas fasilitas wisata memiliki pengaruh yang signifikan terhadap kepuasan pengunjung pemandian air panas Aek Milas Siabu dengan kontribusi sebesar $23,6 \%$, sedangkan sisanya 76,4\% dipengaruhi oleh variabel lain yang tidak diteliti dalam penelitian ini. Dalam hal ini variabel kualitas fasilitas wisata memiliki pengaruh positif terhadap kepuasan pengunjung pemandian air panas Aek Milas Siabu.

Kata Kunci Pengaruh, Kualitas Fasilitas Wisata, Kepuasan Pengunjung
\end{abstract}

\begin{abstract}
This research aims to know the influence of the quality of tourism facilities to visitors satisfaction in Aek Milas Siabu Hot Springs. The background of this research is too many visitors complaints about their dissatisfactions. Some of them disappointed with the quality of tourism facilities in Aek Milas Siabu Hot Springs. This is a quantitative research and use simple linear regression technique. This research use questionnaires with 69 visitors as samples and data processing with Software SPSS. From this research researcher know that the quality of tourism facilities have positive and significant influence to visitors satisfaction in Aek Milas Siabu Hot Springs. The contributes of the quality of tourism facilities to visitors satisfaction are 23,6\% and 76,4\% explained by others variables. The quality of tourism facilities have positive effects to visitors satisfaction in Aek Milas Siabu Hot Springs.

Key words Effect, the quality of tourism facilities, visitors satisfaction.
\end{abstract}

\section{PENDAHULUAN}

Rutinitas kehidupan modern yang ditandai dengan aktivitas kehidupan yang sangat sibuk dan monoton telah memunculkan kebutuhan baru bagi sebagian orang. Kebutuhan tersebut adalah kebutuhan rekreasi dan wisata. Dengan berekreasi atau melakukan perjalanan wisata maka kondisi fisik dan mental yang penat dan jenuh akan 
kembali bergairah untuk melaksanakan pekerjaan-pekerjaan rutin yang telah menanti seseorang untuk beberapa hari ke depan.

Frekuensi kegiatan rekreasi atau berwisata bagi setiap orang berbeda-beda. Ada yang melakukan kegiatan rekreasi atau berwisata sebagai agenda mingguan, bulanan, bahkan tahunan. Namun ada juga yang melaksanakannya secara insidental saja tanpa ada perencanaan. Jadi pada dasarnya hampir setiap orang membutuhkan kegiatan rekreasi atau berwisata walaupun frekuensinya bisa berbeda-beda pada setiap orang tergantung kepada kemampuan, kesempatan, maupun volume pekerjaannya sehari-hari. Lokasi yang dipilih dalam kegiatan rekreasi dan wisata ini pun bermacam-macam, mulai dari obyek wisata alam, obyek wisata sejarah, obyek wisata religi, pusat perbelanjaan, kuliner, maupun olahraga.

Dewasa ini kegiatan rekreasi atau wisata bukan hanya dianggap kegiatan melepaskan kejenuhan dan kepenatan seseorang atau sekelompok orang dengan menikmati keindahan alam, napak tilas sejarah, kuliner maupun bentuk wisata lainnya. Namun aktivitas rekreasi dan wisata ini juga telah memunculkan sektor perekonomian yang potensial bagi masyarakat. Di daerah di mana terdapat obyek wisata biasanya akan menjadi pusat aktivitas perekonomian masyarakat. Banyak daerah yang dapat disebutkan sebagai contohnya antara lain: Kota Parapat dengan obyek wisata Danau Toba, Brastagi dengan obyek wisata Gundaling, Bukit Tinggi dengan obyek wisata Jam Gadang, Takengon dengan obyek wisata Danau Laut Tawar, Bali, Lombok, Raja Ampat, Bromo, dan sebagainya. Sektor pariwisata merupakan sektor perekonomian yang potensial dikembangkan di Indonesia. Bentang alam Indonesia memiliki banyak destinasi wisata yang sangat indah berupa danau, sungai, pantai, pegunungan, sumber air panas, dan pemandangan alam lainnya. Di samping itu di Indonesia banyak juga terdapat obyek wisata sejarah antara lain Candi Borobudur dan candi-candi lainnya, situs-situs peninggalan zaman megalitikum, bangunan masjid bersejarah, dan sebagainya. Indonesia juga kaya akan seni budaya yang unik, kuliner yang lezat, dan masyarakat yang ramahtamah.

Pemerintah Republik Indonesia sangat serius untuk mengelola sektor pariwisata ini untuk kemakmuran rakyat. Bukan hanya pemerintah pusat tetapi pemerintah daerah setingkat kabupaten/kota juga melihat sektor pariwisata ini sebagai sektor perekonomian yang penting. Sehingga hampir di setiap lingkungan Pemerintah Kabupaten/Kota di Indonesia dibentuk Dinas Pariwisata yang khusus bertugas untuk mengelola dan memajukan potensi wisata di daerahnya. Selain itu banyak juga anggota masyarakat dengan kesadaran sendiri mengelola lokasi obyek wisata di daerahnya masing-masing setelah menyadari potensi dan dampaknya secara ekonomi bagi kesejahteraan mereka.

Mandailing Natal merupakan salah satu kabupaten yang berada di wilayah Sumatera Utara. Kabupaten ini merupakan wilayah paling ujung Sumatera Utara dan berbatasan langsung dengan Propinsi Sumatera Barat. Kabupaten Mandailing Natal memiliki beragam destinasi wisata potensial yang kebanyakan belum dikelola secara maksimal dan dikenal di tingkat nasional. Sebagai contoh dapat disebutkan antara lain: Kawah Sorik Marapi, Perkampungan tradisional Sibanggor, Meriam Raffles, Taman Nasional Batang Gadis, Legenda Sampuraga, Bagas Godang Panyabungan Tonga, Bagas Godang Huta Godang, Suku Lubu, Aek Milas Putusan, Aek Milas Hutaraja, Aek Milas Siabu, Pantai Natal, Pantai Kura-kura, Air Terjun Carocek, Air terjun Gala-Gala, Situs Candi Simangambat, Pulau Unggeh, dan sebagainya.

Di antara obyek wisata tersebut ada beberapa obyek wisata alam berupa pemandian air panas yaitu: Aek Milas Putusan, Aek Milas Hutaraja, dan Aek Milas Siabu. 
Sumber air panas ini muncul disebabkan sebagian wilayah Kabupaten Mandailing Natal berada di jalur Pegunungan Bukit Barisan dan memiliki gunung berapi yang masih aktif yaitu Gunung Sorik Marapi. Salah satu sumber air panas yang sudah dimanfaatkan masyarakat sebagai tempat rekreasi dan berwisata adalah pemandian air panas "Aek Milas Siabu". Pemandian air panas ini berada di tempat yang cukup strategis karena berada tidak jauh dari jalan lintas Sumatera. Untuk mencapai lokasi ini bias digunakan kenderaan roda dua maupun roda empat dengan kondisi jalan aspal. Obyek wisata Aek Milas Siabu ini tepatnya berada di Kelurahan Siabu, Kecamatan Siabu, Kabupaten Mandailing Natal, Provinsi Sumatera Utara. Lokasi obyek wisata ini berada tidak jauh dari pemukiman masyarakat.

Sebenarnya obyek wisata Aek Milas Siabu ini cukup potensial untuk dikembangkan sehingga berdampak bagi kehidupan dan perekonomian masyarakat sekitarnya. Lokasinya yang berada di jalur lintas Sumatera memberikan peluang yang lebih besar untuk dikunjungi wisatawan dari segala lapisan umur maupun profesi. Berbeda dengan lokasi wisata yang berada di pedalaman dan jauh dari pemukiman masyarakat yang kemungkinan besar hanya dapat dikunjungi oleh wisatawan yang kondisi fisiknya masih kuat. Selain itu suhu air di pemandian Aek Milas Siabu ini termasuk kategori menengah, sehingga cocok digunakan sebagai tempat pemandian karena suhunya tidak membahayakan kesehatan dan keselamatan manusia. Lokasi obyek wisata ini juga dikelilingi oleh pemandangan alam yang menarik berupa perbukitan dan juga hamparan persawahan masyarakat. Jika dikelola dengan baik sebenarnya lokasi wisata ini dapat memberikan dampak positif bagi masyarakat sekitarnya, khususnya masyarakat Kelurahan Siabu.

Potensi yang dimiliki oleh obyek wisata Aek Milas Siabu ini belum sepenuhnya dikelola dengan baik. Hal ini tergambar dari informasi yang disampaikan masyarakat maupun hasil wawancara dengan beberapa orang pengunjung Aek Milas Siabu. Ibu Siti Khadijah mengatakan bahwa ia sering berkunjung ke Aek Milas Siabu namun ia mengeluhkan fasilitas toilet yang belum memadai. Sejalan dengan hal di atas Bapak Rif'an, salah seorang warga Desa Simaninggir Siabu, menyatakan bahwa jika fasilitas untuk pengunjung Aek Milas Siabu dilengkapi dengan baik maka ia yakin obyek wisata ini akan menjadi tempat favorit untuk dikunjungi masyarakat Kabupaten Mandailing Natal, bahkan dari luar daerah. Sementara itu Sari, seorang pengunjung, mengatakan ia sering membawa makanan dari rumahnya ketika akan berkunjung ke Aek Milas Siabu karena terbatasnya pilihan makanan dan jajanan yang tersedia di warung yang ada di lokasi obyek wisata tersebut. Bouk, seorang penjual makanan di lokasi obyek wisata Aek Milas Siabu, mengatakan bahwa ia hanya menjual makanan yang sederhana saja karena keterbatasan ketrampilan dan modal yang dimilikinya. Ia juga mengatakan jumlah ratarata pengunjung yang datang tidak terlalu berbeda dari tahun-tahun sebelumnya. Lain halnya dengan Masali, seorang mahasiswa, mengatakan bahwa ia rutin berkunjung ke Aek Milas Siabu karena rumahnya tidak terlalu jauh dari lokasi obyek wisata tersebut. Ia sering membeli rokok dan shampoo di warung yang ada di sekitar Aek Milas Siabu.

Dari uraian wawancara dan informasi tersebut di atas terlihat bahwa sebagian masyarakat berpendapat bahwa fasilitas yang tersedia di lokasi obyek wisata Aek Milas Siabu masih belum sesuai dengan harapan nasabah. Keadaan ini akan menimbulkan ketidakpuasan para pengunjung dan bahkan mengurangi minat mereka untuk berkunjung ke Aek Milas Siabu. Padahal jika obyek wisata ini dikembangkan sehingga pengunjungnya ramai maka kehidupan perekonomian masyarakat sekitarnya juga akan meningkat. Oleh karena itu perlu diteliti pengaruh kualitas fasilitas wisata dan 
gambarannya serta pengaruhnya terhadap kepuasan pengunjung obyek wisata pemandian air panas Aek Milas Siabu.

\section{TINJAUAN PUSTAKA \\ 2.1. Kepuasan Pengunjung}

Istilah "kepuasan" merupakan istilah istilah yang popular dalam bidang kajian manajemen khususnya bidang manajemen pemasaran. Seorang konsumen sebelum membeli sebuah produk atau jasa biasanya telah memiliki gambaran tertentu tentang produk atau jasa yang akan diterimanya nanti dari penjual. Sebagian besar keputusan pembelian didahului dengan pencarian informasi oleh calon konsumen tentang produk dan jasa yang akan dibelinya. Andayani (2014:24) menyatakan bahwa informasi ini bisa diperoleh dari berbagai sumber: 1) melalui sumber pribadi antara lain keluarganya sendiri, teman-teman, jiran, maupun para kenalannya, 2) melalui sumber niaga antara lain periklanan, petugas penjualan, penjualan kemasan dan pemajangan, 3) melalui sumber umum antara lain media massa dan organisasi konsumen, 4) melalui sumber pengalaman antara lain karena pernah menangani, menguji dan mempergunakan produk atau jasa tersebut. Dari informasi yang terkumpul maka calon konsumen akan memiliki gambaran tentang produk atau jasa yang akan dinikmatinya nanti setelah membelinya dari penjual maupun produsen. Gambaran produk atau jasa ini sekaligus menjadi ekspektasi atau harapannya terhadap produk atau jasa tersebut.

Selanjutnya kepuasan konsumen merupakan persepsi individu dari kinerja produk atau jasa dalam kaitannya dengan harapan-harapan sebelumnya. Dapat dikatakan bahwa kepuasan konsumen adalah hasil yang dirasakan oleh konsumen yang mendapatkan kinerja sebuah perusahaan yang sesuai dengan harapannya. Konsumen akan merasa puas jika harapan mereka terpenuhi dan mereka akan sangat gembira jika harapan mereka terlampaui. Kepuasan konsumen muncul dari dalam hati konsumen dengan perasaan senang atau kecewa setelah membandingkan persepsi atau kesannya terhadap kinerja atau hasil suatu produk dan harapan-harapannya sebelumnya. Jika kinerja yang dirasakan memenuhi harapan maka konsumen akan merasa puas, sebaliknya jika tidak memenuhi harapannya maka konsumen akan kecewa dan merasa tidak puas. Kepuasan yang tinggi terhadap kinerja produk atau jasa akan menciptakan kelekatan emosional terhadap merek tertentu, bukan hanya sekedar kesukaan atau preferensi rasional, akhirnya akan tercipta loyalitas atau kesetiaan konsumen yang tinggi.

Fokus pada kepuasan konsumen merupakan ciri dan pembeda manajemen pemasaran dengan konsep penjualan. Seorang pemasar sebenarnya perlu fokus pada usaha-usaha untuk memberikan kepuasan yang maksimal kepada konsumen dalam mengonsumsi produk atau jasa yang mereka tawarkan dan bukan fokus pada peningkatan volume penjualan produk. Drake seperti dikutip oleh Hurriyati (2015:24) mengatakan bahwa konsumen yang terpuaskan dengan sendirinya akan melakukan pembelian berulang bahkan dengan volume yang yang lebih besar. Mereka juga akan menjadi iklan gratis yang dengan suka rela mengajak dan merekomendasikan produk atau jasa yang dihasilkan perusahaan tanpa dibayar.

Andayani (2013:26) menyatakan bahwa kepuasan konsumen dipengaruhi oleh kualitas produk, hargadan faktor-fakto yang bersifat pribadi. Salah satu dari beberapa faktor yang memiliki kaitan erat dengan kepuasan konsumen adalah persepsi konsumen tentang kualitas jasa yang berfokus pada lima dimensi kualitas jasa dan dikenal dengan istilah TERRA yaitu: tangible, empathy, reliability, responsiveness, dan assurance. 
Para pemasar perlu mengetahui apa yang akan terjadi jika konsumen memperoleh kepuasan atau ketidakpuasan setelah mengonsumsi produk atau jasa yang ditawarkan. Perlu diketahi bahwa kepuasan dan ketidakpuasan konsumen atas produk atau jasa akan berpengaruh pada pola perilaku selanjutnya. Perilaku ini akan muncul setelah terjadi proses pembelian (post purchase action). Ratnasari (2011:119) menyatakan apabila konsumen puas maka dia akan menunjukkan besar kemungkinan untuk kembali membeli produk yang sama. Konsumen yang puas juga cenderung memberikan referensi yang baik terhadap produk/jasa kepada orang lain. Namun berbeda halnya jika seorang konsumen merasakan ketidakpuasan (dissatisfied). Pelanggan yang tidak puas dapat melakukan tindakan pengembalian produk atau secara ekstrem, dapat mengajukan gugatan terhadap perusahaan melalui jalur hukum, dan tentunya akan memberikan rekomendasi negatif terhadap perusahaan kepada orang lain. Dengan demikian perusahaan, lembaga, maupun organisasi harus mengantisipasinya dengan baik, karena seorang konsumen yang tidak puas akan dapat merusak citra perusahaan. Setiap perusahaan seharusnya mempersiapkan cara-cara tertentu untuk meminimalisir jumlah konsumen yang tidak puas setelah proses pembelian terjadi.

Istilah konsumen memiliki beberapa sebutan tergantung kepada jenis usaha dan bisnis yang digeluti perusahaan atau lembaga. Dalam dunia perbankan dan lembaga keuangan konsumen disebut dengan nasabah. Dalam dunia kesehatan konsumen disebut dengan pasien. Dalam bisnis pariwisata dan hiburan termasuk perhotelan, konsumen disebut dengan tamu, pengunjung, atau wisatawan. Dalam tulisan ini konsumen yang dimaksud pengunjung obyek wisata pemandian air panas Aek Milas Siabu.

\subsection{Fasilitas Wisata}

Salah satu dimensi yang memiliki kaitan erat dengan kepuasan konsumen adalah dimensi tangible ( bukti fisik). Yazid(2008:104-105) mengemukakan bahwa aspek tangible ini dapat mencakup penampilan fasilitas atau elemen-elemen fisikal, peralatan, personil, dan material-material lainnya. Tujuannya adalah untuk memperkuat kesan tentang kualitas, kenyamanan dan keamanan dari jasa yang ditawarkan kepada konsumen. Karena aspek tangible, khususnya lingkungan fisik atau fasilitas, merupakan salah satu aspek organisasi jasa yang dengan mudah terlihat oleh konsumen, maka penting kiranya lingkungan fisik ini, apapun bentuknya, harus didesain dalam cara yang konsisten dengan strategi posisi. Dalam manajemen pemasaran pariwisata aspek tangible, yang meliputi lingkungan fisik dan fasilitas, memegang peranan penting dalam memuaskan konsumen atau pengunjung. Dapat dibayangkan betapa efektifnya Taman Impian Jaya Ancol di Jakarta menggunakan bukti fisik jasa-jasanya untuk menarik konsumen. Tampilan bangunan-bangunannya atau lampu yang warna-warni, musiknya, sarana-sarana yang fantastik, karakter-karakter hiburan yang telah disesuaikan, semuanya menekankan perasaan senang dan menarik yang ingin ditanamkan oleh pengelola Taman Impian Jaya Ancol di benak setiap konsumennya.

Wisatawan atau pengunjung suatu lokasi obyek wisata akan membutuhkan banyak fasilitas wisata untuk mewujudkan apa yang menjadi impian mereka dalam mengunjungi lokasi obyek wisata. Dapat dibayangkan banyaknya kebutuhan fasilitas wisata yang diperlukan wisatawan mulai dari mulai memasuki hingga ke luar dari suatu lokasi obyek wisata. Ketika memasuki lokasi wisata mereka membutuhkan lokasi parkir yang aman dan lapang, tempat beristirahat berupa pondok maupun penginapan, berbagai macam makanan dan minuman, toilet, tempat ibadah, arena bermain anak-anak, peralatan mandi, keranjang sampah, jaringan internet, penjual pulsa dan kuota internet, penjual 
cinderamata, lokasi untuk berfoto, toko obat, dan lain sebagainya. Fasilitas-fasilitas tambahan tersebut sangat dibutuhkan oleh wisatawan di samping fasilitas utama berupa keindahan dan kenyamanan yang ditawarkan oleh obyek wisata itu sendiri. Kemudahan dalam memenuhi kebutuhan para wisatawan selama berwisata tersebut akan menciptakan perasaan nyaman bagi mereka. Sehingga mereka akan merasa puas dalam menikmati kunjungan ke lokasi wisata tersebut. Diharapkan dengan kepuasan yang mereka rasakan maka mereka akan datang berkunjung kembali dan merekomendasikan lokasi wisata tersebut kepada orang lain.

\subsection{Manajemen Industri Pariwisata}

Masalah pariwisata saat ini telah menjadi salah satu sektor andalan pemasukan devisa yang cukup besar bagi suatu negara. Dalam lingkup yang lebih kecil, taraf perekonomian masyarakat yang tinggal di sekitar lokasi obyek wisata akan sangat dipengaruhi banyaknya wisatawan yang datang berkunjung. Sektor pariwisata telah menjelma menjadi industri yang disebut dengan industri pariwisata dan menghasilkan produk-produk wisata untuk dipasarkan. Untuk memajukan sektor pariwisata, diperlukan suatu penanganan khusus dan juga memerlukan suatu manajemen yang baik. Alma (2018:345) mengatakan bahwa industri pariwisata adalah kumpulan dari macam-macam perusahaan yang secara bersama menghasilkan barang-barang dan jasa yang dibutuhkan para wisatawan pada khususnya dan traveler pada umumnya, selama dalam perjalanannya. Kumpulan macam-macam perusahaan yang dimaksudkan antara lain: agen perjalanan, angkutan/transportasi, akomodasi/perhotelan, catering/kuliner, pemandu wisata, usaha cinderamata/souvenir dan lainnya.

Manajemen industri pariwisata dapat ditinjau dari segi makro atau mikro. Dari segi makro berarti pengaturan oleh pihak pemerintah secara keseluruhan. Pemerintah, baik pemerintah pusat dan daerah, perlu menetapkan peraturan-peraturan tentang kepariwisataan. Pemerintah menetapkan cara-cara atau perizinan membuka usaha dan bisnis pariwisata, peraturan untuk memasuki suatu daerah, pemerintah juga bertanggung jawab dengan keamanan para turis yang datang ke wilayahnya. Sedangkan dari segi mikro artinya manajemen yang dilaksanakan oleh lembaga-lembaga yang memberi pelayanan pada para wisatawan, seperti manajemen perhotelan, agen perjalanan maupun perusahaan transportasi dan sebagainya. Semua usaha ini hendaknya diarahkan kepada pelayanan yang dapat memuaskan para wisatawan.

Oleh karena itu tujuan dari manajemen industri pariwisata ini adalah: a) menimbulkan kesan baik para wisatawan terhadap daerah yang ia kunjungi, sehingga ia merasa aman, tertarik, betah, dan berhasrat menganjurkan rekan-rekannya untuk mengikuti jejaknya, b)meningkatkan hubungan antara daerah asal wisatawan dengan daerah obyek-obyek wisata sehingga kunjungan dari warganya makin sering diadakan.

\subsection{Penelitian Terdahulu}

Penelitian dilakukan oleh Putri (Putri, 2017), tentang Pengaruh Kualitas Jasa Terhadap Kepuasan Pengunjung Obyek Wisata Gunung Pindul. Dalam penelitian ini pendekatan yang digunakan ialah kualitatif dengan analisis regresi linear berganda dan analisis uji beda (ANOVA). Dari hasil analisis regresi linear berganda diketahui bahwa variabel yang terdapat pada penelitian ini meliputi bukti langsung (tangibles), kehandalan (reliability), ketanggapan (reponsiveness), jaminan (assurance) dan empati (emphaty), terbukti berpengaruh positif dan signifikan terhadap kepuasan pengunjung obyek wisata Gua Pindul. Sedangkan hasil dari uji beda terbukti bahwa adanya perbedaan tingkat kualitas jasa pada tiap-tiap pengelola atau sekretariat obyek wisata Gua Pindul. 
Peneliti dilakukan oleh Stevianus (Stevianus, 2014), tentang Pengaruh Atraksi Wisata, Fasilitas dan Kualitas Pelayanan Terhadap Kepuasan Pengunjung di Taman Margasatwa Ragunan Jakarta. Setelah melakukan kajian literatur dan penyusunan hipotesis, data yang dikumpulkan melalui kuesioner pada 100 pengunjung Taman Margasatwa Ragunan Jakartayang diperoleh menggunakan teknik sampling sistematik. Kemudian dilakukan analisis data yang diperoleh dengan menggunakan analisis regresi berganda. Analisis ini mencakup: validitas dan reliabilitas, uji asumsi klasik, analisis regresi berganda, pengujian hipotesis melalui uji $\mathrm{t}$ dan $\mathrm{F}$, dan analisis koefisien determinasi (R2). Uji F menunjukkan bahwa variabel atraksi wisata yang berpengaruh signifikan terhadap kepuasan pengunjung dan variabel lainnya hanya berpengaruh positif dan tidak signifikan terhadap kepuasan pengunjung. Angka Adjusted R square sebesar 0,20 menunjukkan bahwa 20 persen variabel kepuasan pengunjung dapat dijelaskan melalui ketiga variabel independen dalam persamaan regresi. Sedangkan sisanya 80 persen dijelaskan oleh variabel lain diluar ketiga variabel yang digunakan dalam penelitian ini.

Penelitian dilakukan oleh Sulistiyana (Sulistiyana, 2015) tentang Pengaruh Fasilitas Wisata dan Harga Terhadap Kepuasan Konsumen (Studi pada Museum Satwa). Hasil penilitian menunjukkan bahwa variabel Fasilitas Wisata memiliki pengaruh signifikan terhadap Kepuasan Konsumen. Variabel Harga memiliki pengaruh signifikan terhadap Kepuasan Konsumen. Hasil uji f menunjukan bahwa kedua variabel bebas Fasilitas Wisata dan Harga secara simultan memiliki pengaruh signifikan terhadap Kepuasan Konsumen. Angka Adjusted R Square 0,537 menunjukan bahwa 53,7 persen variabel Kepuasan Konsumen dapat dijelaskan oleh kedua variabel bebas yakni Fasilitas Wisata dan Harga, sedangkan sisanya sebesar 46,3 persen diterangkan oleh variabel lain yang tidak diajukan dalam penelitian ini.

Penelitian dilakukan oleh Suchaina (Suchaina, 2014), tentang Pengaruh Kualitas Sarana dan Prasarana Terhadap Peningkatan Jumlah Pengunjung Wisata Danau Ranu Grati.. Adapun hasil dari penelitian ditemukan ada beberapa fasilitas sarana dan prasana yang masih berada dibawah standart dan perlu perbaikan dan perawatan yang serius, seperti lantai dan gazebo yang ada di area pendopo Danau Ranu dalam kondisi retak serta gladak/jembatan kayu yang ada di Danau Ranu Grati. Selain itu area tempat bermain anak dan perahu bebek masih ada beberapa yang perlu diperbaiki.Secara keseluruhan kualitas sarana dan prasarana yang ada di obyek wisata Danau Ranu sudah cukup baik tetapi masih perlu adanya perbaikan pada beberapa sarana yang ada seperti pendopo dan terdapat 1 unit perahu bebek yang bocor dan pedalnya sudah agak rusak. Kualitas sarana dan prasana memiliki pengaruh terhadap peningkatan jumlah pengunjung terbukti dengan upaya yang dilakukan oleh pengelola wisata Danau Ranu tahun sebelumnya jumlah pengunjung mengalami kenaikan pada tiap tahunnya.

\section{METODOLOGI PENELITIAN}

Jenis penelitian ini yang digunakan adalah penelitian kuantitatif. Adapun Populasi yang dipakai dalam penelitian ini adalah para pengunjung obyek wisata pemandian air panas Aek Milas Siabu yang jumlahnya tidak dapat ditentukan (tidak dapat diketahui) karena jumlahnya setiap saat terus bertambah.

Untuk mengetahui jumlah sampel yang digunakan dalam penelitian ini, maka digunakan rumus sampel tidak diketahui sesuai dengan pendapat Husein Umar (2013:78) berikut: 


$$
\mathrm{n}=\mathrm{Z}^{2} \mathrm{P}(1-\mathrm{P}) / \mathrm{e}^{2}
$$

Keterangan:

$\mathrm{n}=$ Ukuran sampel

$\mathrm{Z}=$ Mengacu pada tingkat kepercayaan. Dalam penelitian ini ditentukan sebesar $90 \%$ maka nilai $\mathrm{Z}$ adalah 1,65 .

$\mathrm{p}=$ Variasi populasi. Variasi populasi disini dinyatakan dalam bentuk proporsi, karena tidak ada data pendahuluan mengenai populasi, variasi populasi diasumsikan heterogen (dengan proporsi 50:50). Jadi, 0,5 (1-p) $=0,5 \times 0,5=0,25$

$\mathrm{e}=$ Kesalahan sampel yang ditolerir, dalam penelitian ini sebesar $10 \%$ dengan menggunakan rumus diatas, maka diperoleh banyaknya sampel sebagai berikut:

$$
\begin{aligned}
& \mathrm{n}=\mathrm{Z}^{2} \mathrm{P}(1-\mathrm{P}) / \mathrm{e}^{2} \\
& \mathrm{n}=(1,65)^{2}(0,5)(1-0,5) /(0,1)^{2} \\
& \mathrm{n}=69
\end{aligned}
$$

Jadi sampel dalam penelitian ini adalah sebanyak 69 orang. Teknik sampling yang digunakana adalah accidental sampling.

Instrumen penelitian ini adalah menggunakan angket sebanyak 22 butir untuk variabel kualitas fasilitas wisata $(\mathrm{X})$ dan 10 butir untuk variabel kepuasan pengunjung

\begin{tabular}{|c|c|c|c|c|}
\hline No & Variabel & Dimensi & No & Pernyataan angket \\
\hline \multirow[t]{9}{*}{2} & $\begin{array}{c}\text { Kualitas } \\
\text { Fasilitas } \\
\text { Wisata }(\mathrm{X})\end{array}$ & \multirow[t]{2}{*}{ Obyek } & 1 & $\begin{array}{l}\text { Saya sukamandi air panas di } \\
\text { pemandian air panas Aek Milas } \\
\text { Siabu }\end{array}$ \\
\hline & & & 2 & $\begin{array}{l}\text { Suhu air di pemandian air panas } \\
\text { Aek Milas Siabu sesuai untuk } \\
\text { tubuh }\end{array}$ \\
\hline & & \multirow[t]{3}{*}{ Aksesibilitas } & 3 & $\begin{array}{l}\text { Jalan ke Aek Milas Siabu } \\
\text { kondisinya bagus }\end{array}$ \\
\hline & & & 4 & $\begin{array}{l}\text { Lapangan parkir di Aek Milas } \\
\text { Siabu lapang dan luas }\end{array}$ \\
\hline & & & 5 & $\begin{array}{l}\text { Lokasi pemandian air panas Aek } \\
\text { Milas Siabu dilengkapi dengan } \\
\text { petunjuk arah }\end{array}$ \\
\hline & & \multirow[t]{2}{*}{ Catering service } & 6 & $\begin{array}{l}\text { Banyak pilihan kuliner yang } \\
\text { tersedia di lokasi pemandian air } \\
\text { panas Aek Milas Siabu }\end{array}$ \\
\hline & & & 7 & $\begin{array}{l}\text { Di sekitar lokasi Aek Milas Siabu } \\
\text { banyak kios yang menjual } \\
\text { kebutuhan pengunjung }\end{array}$ \\
\hline & & Transportasi & 8 & $\begin{array}{l}\text { Lokasi pemandian air panas Aek } \\
\text { Milas Siabu mudah dijangkau } \\
\text { kenderaan umum dari segala arah }\end{array}$ \\
\hline & & Aktifitas rekreasi & 9 & $\begin{array}{l}\text { Bak mandi di pemandian air panas } \\
\text { Aek Milas Siabu terawat dengan } \\
\text { baik }\end{array}$ \\
\hline
\end{tabular}
(Y). Pernyataan angket untuk setiap variabel adalah seperti pada tabel berikut:

Tabel 1

Daftar pernyataan angket 


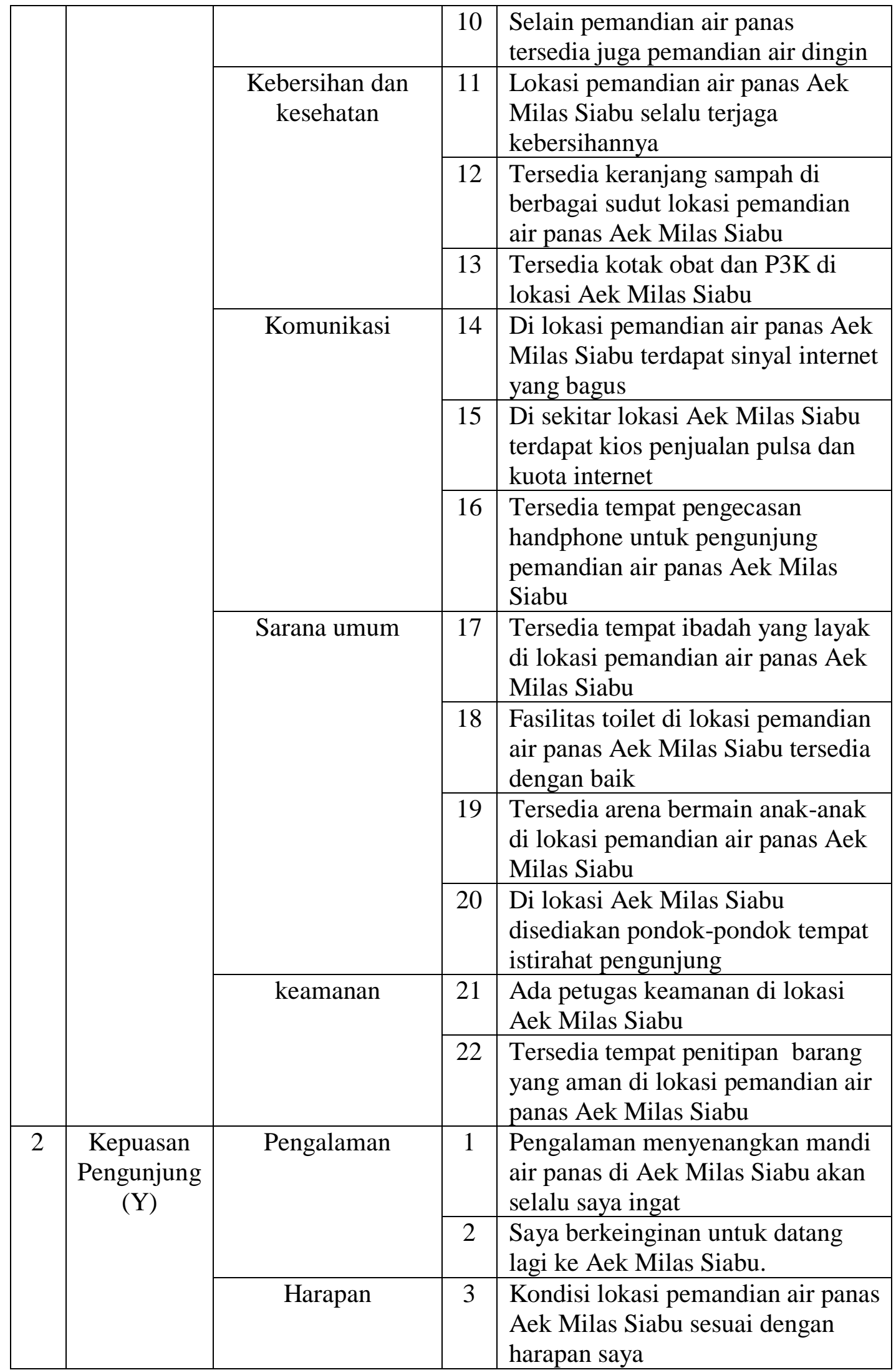




\begin{tabular}{|c|c|c|}
\hline & 4 & $\begin{array}{l}\text { Fasilitas yang ada di lokasi Aek } \\
\text { Milas Siabu kondisinya baik sesuai } \\
\text { dengan harapan saya }\end{array}$ \\
\hline \multirow[t]{2}{*}{ Merekomendasikan } & 5 & $\begin{array}{l}\text { Saya mengajak teman-teman saya } \\
\text { untuk berkunjung ke Aek Milas } \\
\text { Siabu }\end{array}$ \\
\hline & 6 & $\begin{array}{l}\text { Saya senang bercerita pengalaman } \\
\text { menyenangkan mandi di Aek Milas } \\
\text { Siabu kepada orang lain }\end{array}$ \\
\hline \multirow[t]{2}{*}{$\begin{array}{l}\text { Memenuhi } \\
\text { kebutuhan }\end{array}$} & 7 & $\begin{array}{l}\text { Saya merasa makin bugar setelah } \\
\text { mandi air panas di Aek Milas } \\
\text { Siabu }\end{array}$ \\
\hline & 8 & $\begin{array}{l}\text { Rasa penat yang saya alami hilang } \\
\text { setelah mandi air panas di Aek } \\
\text { Milas Siabu }\end{array}$ \\
\hline \multirow[t]{2}{*}{ Menyenangkan } & 9 & $\begin{array}{l}\text { Lokasi Aek Milas Siabu adalah } \\
\text { tempat yang nyaman untuk } \\
\text { dikunjungi }\end{array}$ \\
\hline & 10 & $\begin{array}{l}\text { Saya merasa senang berekreasi di } \\
\text { pemandian air panas Aek Milas } \\
\text { Siabu }\end{array}$ \\
\hline
\end{tabular}

Bentuk angket yang digunakan adalah angket tertutup yaitu responden memilih jawaban yang telah disediakan sesuai dengan keadaan dirinya. Skala yang digunakan adalah skala likert, skala likert adalah skala yang berisi lima tingkat jawaban yang merupakan skala jenis ordinal. Dimana skala likert ini merupakan cara yang paling sering digunakan dalam menentukan skor. Angket ini menggunakan skala likert yaitu sebagai berikut :

Tabel 2

Skala Likert

\begin{tabular}{|c|c|}
\hline Kategori & Bobot \\
\hline Sangat Setuju & 5 \\
\hline Setuju & 4 \\
\hline Kurang Setuju & 3 \\
\hline Tidak Setuju & 2 \\
\hline Sangat Tidak Setuju & 1 \\
\hline
\end{tabular}

Sebelum angket digunakan untuk mengumpulkan data maka terlebih dahulu dilakukan uji validitas dan uji reliabilitasnya. Butir-butir angket yang valid dan reliabel selanjutnya digunakan untuk mengumpulkan data penelitian dengan cara menyebarkannya kepada responden untuk diisi. Data yang terkumpul dari angket kemudian diolah ke tahapan selanjutnya dengan melakukan uji normalitas dan uji linearitas. Setelah kedua uji prasyarat ini dipenuhi maka selanjutya dilakukan perhitungan koefisien korelasi, persamaan regresi, koefisien determinasi, dan uji signifikansi (uji t).

\section{HASIL PENELITIAN}

\section{Uji Instrumen}

Berdasarkan uji validitas instrumen (angket) yang telah dilakukan ternyata sebanyak 22 butir angket untuk Kualitas Fasilitas Wisata(X) dinyatakan valid dan 10 butir 
untuk variabel Kepuasan Pengunjung (Y) juga dinyatakan valid. Sehingga tahapan uji reliabilitas dapat dilanjutkan untuk semua butir angket yang valid tersebut.

Dari uji reliabilitas yang dilakukan diketahui bahwa angket sebanyak 22 butir angket untuk Kualitas Fasilitas Wisata(X) dinyatakan reliabel dan 10 butir untuk variabel Kepuasan Pengunjung (Y) juga dinyatakan reliabel.

\section{Uji Prasyarat}

Teknik uji normalitas yang digunakan adalah teknik grafik. Setelah dilakukan pengolahan data diperoleh grafik sebagai berikut:

\section{Gambar 1}

\section{Output SPP untuk uji normalitas}

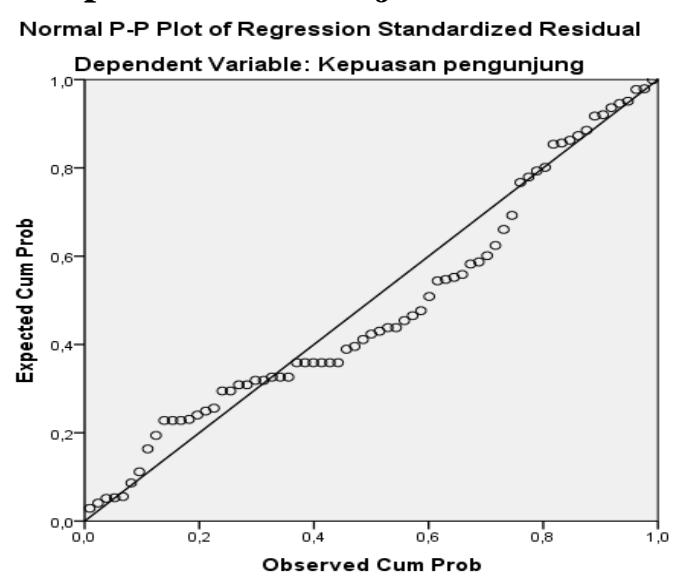

Dari hasil output SPSS uji normalitas di atas dapat dilihat bahwa data menyebar di sekitar garis diagonal dan mengikuti arah garis diagonal tersebut. Artinya model regresi memenuhi asumsi normalitas..

Selanjutnya dilakukan uji linieritas dan diperoleh output SPSS sebagai berikut:

Tabel 3

Output SPSS untuk uji linearitas

\begin{tabular}{|c|c|c|c|c|c|c|c|}
\hline \multicolumn{8}{|c|}{ ANOVA Table } \\
\hline & & & $\begin{array}{l}\text { Sum of } \\
\text { Squares }\end{array}$ & df & $\begin{array}{l}\text { Mean } \\
\text { Square }\end{array}$ & $\mathrm{F}$ & Sig. \\
\hline \multirow{5}{*}{$\begin{array}{l}\text { Kepuasan } \\
\text { pengunjung } \\
* \text { Kualitas } \\
\text { Fasilitas } \\
\text { Wisata }\end{array}$} & Between & (Combined) & 530,123 & 22 & 24,097 & 2,318 &, 008 \\
\hline & Groups & Linearity & 237,894 & 1 & $\begin{array}{r}237,89 \\
4\end{array}$ & $\begin{array}{r}22,88 \\
6\end{array}$ &, 000 \\
\hline & & $\begin{array}{l}\text { Deviation } \\
\text { from } \\
\text { Linearity }\end{array}$ & 292,229 & 21 & 13,916 & 1,339 & ,201 \\
\hline & Within G & ups & 478,167 & 46 & 10,395 & & \\
\hline & Total & & 1008,290 & 68 & & & \\
\hline
\end{tabular}

Sumber: Output SPSS

Dari output SPSS di atas dapat diketahui bahwa signifikansi pada Linearity adalah sebesar 0,000. Karena signifikansi kurang dari 0,10 maka dapat disimpulkan bahwa 
antara variabel Kualitas Fasilitas Wisata (X) dan Kepuasan Pengunjung (Y) terdapat hubungan yang linear.

\section{Uji Koefisien Korelasi (r)}

Dari output SPSS diperoleh tabel berikut:

\section{Tabel 4}

Hasil Uji Koefisien Korelasi

\begin{tabular}{|llrr|}
\hline \multicolumn{3}{c|}{ Correlations } \\
\hline & \multicolumn{1}{c|}{$\begin{array}{c}\text { Kualitas } \\
\text { Fasilitas } \\
\text { Wisata }\end{array}$} & $\begin{array}{c}\text { Kepuasan } \\
\text { pengunjung }\end{array}$ \\
\hline Kualitas Fasilitas & Pearson Correlation & 1 &, $486^{* *}$ \\
Wisata & Sig. (2-tailed) & &, 000 \\
\cline { 2 - 4 } & $\mathrm{N}$ & 69 & 69 \\
\hline Kepuasan pengunjung & Pearson Correlation &, $486^{* *}$ & 1 \\
\cline { 2 - 4 } & Sig. (2-tailed) &, 000 & 69 \\
\cline { 2 - 4 } & $\mathrm{N}$ & 69 & \\
\hline **. Correlation is significant at the 0.01 level (2-tailed). & \\
\hline
\end{tabular}

Sumber: Output SPSS

Artinya antara variabel Kualitas Fasilitas Wisata (X) dan Kepuasan Pengunjung (Y) memiliki hubungan yang sedang. Hal ini sesuai dengan pendapat Sugiono dalam buku Dwi Priyatno (2008:54) yang menyatakan bahwa nilai $r$ dalam rentang 0,40-0,599 menunjukkan tingkat hubungan yang sedang.

\section{Uji Koefisien Determinasi}

Dari output SPSS diperoleh tabel berikut:

\section{Tabel 5}

Hasil Uji Koefisien Determinasi

\begin{tabular}{|c|c|c|c|c|}
\hline \multicolumn{5}{|c|}{ Model Summary ${ }^{b}$} \\
\hline Model & $\mathrm{R}$ & R Square & $\begin{array}{l}\text { Adjusted R } \\
\text { Square }\end{array}$ & $\begin{array}{l}\text { Std. Error of } \\
\text { the Estimate }\end{array}$ \\
\hline 1 &, $486^{\mathrm{a}}$ & ,236 & 225 & 3,391 \\
\hline \multicolumn{5}{|c|}{ a. Predictors: (Constant), Kualitas Fasilitas Wisata } \\
\hline \multicolumn{5}{|c|}{ b. Dependent Variable: Kepuasan pengunjung } \\
\hline
\end{tabular}

Nilai koefisien determinasi adalah sebesar 0,236. Hal ini menjelaskan bahwa variabel Kualitas Fasilitas Wisata (X) hanya memberikan pengaruh 23,6\% terhadap Kepuasan pengunjung (Y) di obyek wisata pemandian air panas Aek Milas Siabu. Sedangkan sisanya $76,4 \%$ dipengaruhi oleh variabel lain yang tidak diteliti dalam penelitian ini.

\section{Persamaan Regresi}


Dalam penelitian ini dilakukan perhitungan persamaan regresi linier sederhana untuk mengetahui hubungan fungsional antara variabel Kualitas Fasilitas Wisata (X) dan Kepuasan Pengunjung (Y) pada obyek wisata pemandian air panas Aek Milas Siabu.

\section{Tabel 6}

Persamaan regresi

\begin{tabular}{|c|c|c|c|c|c|}
\hline \multicolumn{6}{|c|}{ Coefficients $^{\mathrm{a}}$} \\
\hline \multirow[b]{2}{*}{ Model } & $\begin{array}{r}\text { Unstan } \\
\text { Coef }\end{array}$ & $\begin{array}{l}\text { lardized } \\
\text { cients }\end{array}$ & $\begin{array}{c}\text { Standardize } \\
\text { d } \\
\text { Coefficient } \\
\text { s } \\
\end{array}$ & & \\
\hline & B & Std. Error & Beta & $\mathrm{t}$ & Sig. \\
\hline (Constant) & 15,856 & 3,304 & & 4,799 & ,000 \\
\hline $\begin{array}{l}\text { Kualitas Fasilitas } \\
\text { Wisata }\end{array}$ & ,233 &, 051 & ,486 & 4,549 & ,000 \\
\hline
\end{tabular}

Sumber: Output SPSS

Bersarkan tabel di atas dapat diketahui bahwa nilai konstanta adalah sebesar 15,856 dan koefisien regresi Kualitas Fasilitas Wisata adalah 0,233. Adapun persamaan regresinya adalah:

\section{Kepuasan Pengunjung= 15,856+0,233 Kualitas Fasilitas Wisata}

Dari persamaan di atas dapat disimpulkan bahwa:

a.Konstanta sebesar 15,856 artinya apabila variabel Kualitas Fasilitas Wisata nilainya 0 , maka Kepuasan Pengunjung nilainya 15,856 satuan.

b.Koefisien variabel Kualitas Fasilitas Wisata sebesar 0,233 artinya jika variabel Kualitas Fasilitas Wisata meningkat 1 satuan, maka Kepuasan Pengunjung akan mengalami peningkatan sebesar 0,233 satuan.

\section{Uji t}

Uji t digunakan untuk mengetahui apakah variabel Kualitas Fasilitas Wisata (X) berpengaruh signifikan terhadap Kepuasan Pengunjung (Y) pada obyek wisata pemandian air panas Aek Milas Siabu. Berdasarkan Tabel 6 di atas diperoleh Sig. $(0,000)$ $<\alpha(0,1)$ maka $\mathrm{H}_{0}$ di tolak dan $\mathrm{H}_{\mathrm{a}}$ diterima. Jadi dapat disimpulkan dari hasil uji t yang dilakukan bahwa terdapat pengaruh yang signifikan Kualitas Fasilitas Wisata (X) terhadap Kepuasan Pengunjung (Y) pada obyek wisata pemandian air panas Aek Milas Siabu

\section{Pembahasan}

Dari hasil pengolahan data yang dilakukan ternyata Kualitas Fasilitas Wisata memiliki pengaruh yang signifikan terhadap kepuasan pengunjung obyek wisata pemandian air Panas Aek Milas Siabu. Namun jika dilihat dari besarnya koefisien korelasi diperoleh nilai $\mathrm{R}=0,486$ yang menunjukkan adanya hubungan yang sedang antara Kualitas Fasilitas Wisata dengan kepuasan Pengunjung. Nilai koefisien determinasi yang diperoleh adalah 0,236. Nilai koefisien determinasi ini menjelaskan bahwa variabel Kualitas Fasilitas Wisata (X) hanya memberikan pengaruh 23,6\% terhadap Kepuasan 
pengunjung (Y) di obyek wisata pemandian air panas Aek Milas Siabu. Sedangkan sisanya 76,4\% dipengaruhi oleh variabel lain yang tidak diteliti dalam penelitian ini.

Keterangan di atas mengisyaratkan sebenarnya masih banyak faktor-faktor lain, yang mempengaruhi kepuasan pengunjung pemandian air panas Aek Milas Siabu, yang perlu dieksplorasi dan diteliti lebih lanjut. Hal ini mengingat $76,4 \%$ dari faktor-faktor penentu tersebut belum diungkap dalam penelitian ini. Oleh karena itu penelitian ini bisa dilanjutkan dengan penelitian lanjutan dengan faktor-faktor lain yang relevan antara lain: harga, empati masyarakat, promosi, lokasi, citra, dan lain sebagainya.

Jika dibandingkan dengan penelitian terdahulu maka penelitian ini sejalan dan menguatkan temuan-temuan sebelumnya yang menyatakan bahwa Kualitas Fasilitas Wisata berpengaruh terhadap Kepuasan Pengunjung di beberapa tempat wisata atau taman rekreasi pada penelitian sebelumnya. Penelitian ini juga sejalan dengan teori-teori yang ada di bebarapa literatur manajemen yang menyatakan bahwa salah satu unsur yang mempengaruhi kepuasan konsumen adalah kualitas pelayanan yang diberikan dan dirasakan oleh konsumen.

Memang dalam penelitian ini ditemukan bahwa variabel Kualitas Fasilitas Wisata (X) hanya memberikan pengaruh 23,6\% terhadap Kepuasan pengunjung (Y) di obyek wisata pemandian air panas Aek Milas Siabu. Namun bukan berarti kontribusi faktor ini tidak penting dan bisa diabaikan. Faktor kualitas fasilitas wisata yang ada di pemandian air panas Aek Milas Siabu harus tetap diperhatikan kualitas dan keberadaannya. Misalnya kebersihan bak mandi perlu dijaga, kondisi toilet yang bersih dan bagus, kebersihan mushalla, tempat wudhu, maupun kebersihan sajadah harus dijaga, lapangan parkir yang aman harus tetap disediakan, dan sebagainya. Faktor ini tetap penting untuk menjadi perhatian pengelola pemandian air panas Aek Milas Siabu maupun masyarakat Kelurahan Siabu pada umumnya. Kemudian dari uji regresi linier sederhan yang telah dilakukan diperoleh persamaan sebagai berikut:

\section{Kepuasan Pengunjung $=\mathbf{1 5 , 8 5 6 + 0 , 2 3 3 ~ K u a l i t a s ~ F a s i l i t a s ~ W i s a t a ~}$}

Dari persamaan di atas terlihat bahwa koefisien variabel Kualitas Fasilitas Wisata bernilai positif (+). Hal ini menunjukkan adanya hubungan yang positif atau searah antara variabel Kualitas Fasilitas Wisata dan Kepuasan Pengunjung. Artinya dengan meningkatkan nilai Kualitas Fasilitas Wisata akan meningkatkan Kepuasan Pengunjung pemandian Air Panas Aek Milas Siabu

\section{KESIMPULAN}

Dari hasil penelitian yang telah dilakukan disimpulkan bahwa variabel Kualitas Fasilitas Wisata memiliki pengaruh yang signifikan terhadap Kepuasan Pengunjung pada pemandian air panas Aek Milas Siabu. Variabel Kualitas Fasilitas Wisata memberikan kontribusi sebesar $23,6 \%$ terhadap Kepuasan pengunjung di obyek wisata pemandian air panas Aek Milas Siabu. Sedangkan sisanya 76,4\% dipengaruhi oleh variabel lain yang tidak diteliti dalam penelitian ini. Oleh karena perlu dilakukan penelitian lanjutan dengan variabel-variabel lain yang diperkirakan mempengaruhi Kepuasan Pengunjung selain variabel Kualitas Fasilitas Wisata.

\section{DAFTAR PUSTAKA}

Alma, Buchari (2018), Manajemen Pemasaran dan Pemasaran Jasa, Bandung: CV Alfabeta. 
Andayani, Ni Luh Henny (2014), Manajemen Pemasaran Pariwisata, Yogyakarta: Graha Ilmu.

Hurriyati, Ratih (2015), Bauran Pemasaran dan Loyalitas Konsumen, Bandung: CV Alfabeta.

Priyatno, Dwi (2008), Mandiri Belajar SPSS, Yogyakarta: MediaKom.

Ratnasari, Ririn Tri (2011), Manajemen Pemasaran Jasa, Bogor: Ghalia Indonesia.

Umar, Husein (2013), Metode Penelitian untuk Skripsi dan Tesis, Edisi Kedua, Jakarta: Rajawali Pers.

Yazid, (2008), Pemasaran Jasa: Konsep dan Implementasi, Yogyakarta: Ekonisia.

\section{Sumber Jurnal}

Putri, M. P. (2017). Pengaruh Kualitas Jasa Terhadap Kepuasan Pengunjung Obyek Wisata Gua Pindul. Jurnal Tata Kelola Seni, 1(2), 68-81. https://doi.org/10.24821/jtks.v1i2.1642n Pengunjung Obyek Wisata Gua Pindul. Jurnal Tata Kelola Seni, 1(2), 68-81. https://doi.org/10.24821/jtks.v1i2.1642

Stevianus, S. (2014). Pengaruh Atraksi Wisata, Fasilitas Dan Kualitas Pelayanan Terhadap Kepuasan Pengunjung Di Taman Margasatwa Ragunan Jakarta. Jurnal Ilmiah Ekonomi Bisnis, 19(3), 6022.

Suchaina. (2014). Pengaruh Kualitas Fasilitas Sarana dan Prasarana Terhadap Peningkatan Jumlah Pengunjung Wisata Danau Ranu Grati. Jurnal Psikologi, 2(2), 89-109. http://jurnal.yudharta.ac.id/v2/index.php/ILMUPSIKOLOGI/article/view/1072/938

Sulistiyana, R. (2015). Pengaruh Fasilitas Wisata Dan Harga Terhadap Kepuasan Konsumen (Studi Pada Museum Satwa). Jurnal Administrasi Bisnis S1 Universitas Brawijaya, 25(2), 86214. 